\title{
Supplementation of Pooled Human Milk with Casein Hydrolysate: Energy and Nitrogen Balance and Weight Gain Composition in Very Low Birth Weight Infants
}

\author{
G. PUTET, J. RIGO, B. SALLE, AND J. SENTERRE \\ Department of Neonatology, Hopital Edouard Herriot, Claude Bernard University, Lyon, France [G.P., B.S.] and \\ Department of Pediatrics, State University of Liege, Liege, Belgium [J.R., J.S.]
}

\begin{abstract}
Growth and nitrogen and energy balances were studied with a combined technique of nutrient balance and indirect calorimetry measurement in two groups of eight very low birth weight infants fed pooled pasteurized human milk (HM) or cow's milk casein hydrolysate supplemented HM (HM-Pr). There was no difference in the amount of energy absorbed $(91 \pm 17 \mathrm{kcal} / \mathrm{kg} / \mathrm{day}$ with HM-Pr versus $95 \pm 8$ with HM-P) or in the growth rate. The infants fed HM-Pr had a higher nitrogen intake (602 \pm 80 versus $395 \pm 64 \mathrm{mg} / \mathrm{kg} / \mathrm{day} ; p<0.001$ ), urinary nitrogen excretion $(160 \pm 64$ versus $78 \pm 16 \mathrm{mg} / \mathrm{kg} / \mathrm{day} ; p$ $<0.005)$ and nitrogen retention $(326 \pm 32$ versus $252 \pm 48$ $\mathrm{mg} / \mathrm{kg} / \mathrm{day} ; \boldsymbol{p}<0.01$ ). They also had increased plasma concentrations of essential amino acids, urea nitrogen, and total protein without metabolic imbalance. Energy expenditure was higher $(58$ versus $49 \mathrm{kcal} / \mathrm{kg} / \mathrm{day} ; p<0.005)$ and energy storage lower (33 versus $47 \mathrm{kcal} / \mathrm{kg} / \mathrm{day} ; p<0.05$ ) with HM-Pr. In percent of weight gain, protein and fat accretion represented 12 and $14 \%$ in HM-Pr group versus 10 and $27 \%$ in HM group. Very low birth weight infants fed casein hydrolysate supplemented pooled HM achieved a growth rate and a weight gain composition similar to the fetus. (Pediatr Res 21: 458-461, 1987)
\end{abstract}

\section{Abbreviations}

HM, pooled pasteurized human milk

HM-Pr, pooled pasteurized human milk supplemented with hydrolyzed cow's milk casein

$R Q$, respiratory quotient

$\mathrm{VO}_{2}$, oxygen consumption

$\mathrm{VCO}_{2}$, carbon dioxide production

VLBW, very low birth weight

VLBW infants fed pooled pasteurized human milk have a growth rate and a nitrogen retention lower than those fed a preterm formula (1-5). Lower protein, urea, and hemoglobin levels $(6,7)$ have also been reported in these infants suggesting that the protein content of pooled human milk is not adequate for the VLBW infant. In a previous study (1) we have shown that VLBW infants fed a preterm formula had adequate protein retention but a high rate of fat deposition, whereas those fed

Received June 4, 1986; accepted December 9, 1986.

Reprint requests Dr. G. Putet, Department of Neonatology, Hopital Edouard Herriot, Place d'Arsonval, 69437 Lyon Cedex 03 France.

Supported by a grant from University Claude Bernard (Lyon) and by an INSERM Contract (PRC 123.022). pooled pasteurized human milk had a low protein retention but also a high rate of fat deposition. These data suggested that protein, rather than energy, should be added to pooled human milk.

The aim of the present study was to compare nutrient and energy balance in two groups of VLBW boys fed either pooled human milk or pooled human milk supplemented with hydrolyzed cow's milk casein.

\section{MATERIALS AND METHODS}

Infants. Eight VLBW boys of appropriate weight for gestational age were investigated in each group (Table 1). Informed parental consent was obtained for each infant. None of the infants had any medical problem at the time of the study.

Feeding. The infants received an amino acid and glucose solution given parenterally from admission until oral feeding had reached an adequate volume. For all infants oral feeding was started within 24 to $48 \mathrm{~h}$ with pasteurized pooled expressed human milk. Once the full diet had been reached, the infants either continued on pooled HM (HM group) or on pooled HM supplemented with cow's milk casein hydrolysate (HM-Pr group). The casein hydrolysate (Peptones, Gallia, France), which is produced by enzymatic hydrolysis of cow's milk casein, consists mainly of polypeptides with a molecular weight below 3500 daltons and has a low free amino acid and fat content (Table 2). In practice $1 \mathrm{~g}$ of casein hydrolysate is mixed with $100 \mathrm{ml}$ of pooled HM. This increases slightly the total energy content of $\mathrm{HM}(+4.3 \mathrm{kcal} / \mathrm{dl})$ but changes the nonprotein energy content $(+0.14 \mathrm{kcal} / \mathrm{dl})$ very little. In the HM-Pr group the study was performed after at least 2 wk of full feeding with the proteinsupplemented milk. At the time of the study all infants were fed by nasogastric tube every $3 \mathrm{~h}$ and were growing steadily.

Nutritional balance. The nutritional balance consisted of precise measurements of intakes and excreta over a 3-day period, during which the infant lay on a metabolic bed placed within an incubator. This method has been previously reported $(1,8)$. The approximate volume of milk needed for the entire study was pooled, carefully mixed, and an aliquot taken for chemical analysis. The total amount of milk to be given was then measured precisely and divided into "ready-to-feed" bottles. Syringes and nasogastric tubes used for gavage feeding were kept for analysis of the residue. Urine and stools were collected separately (1) and stored at $-20^{\circ} \mathrm{C}$ until analysis. From aliquots of prepared milk, residue of milk, fecal homogenate, and urine, nitrogen was determined according to the micro-Kjeldahl method. The fat content was determined by gravimetric methods $(1,9)$. Lactose in milk was determined by an enzymatic method using the Boehringer lactose Assay Kit (Boehringer, Mannheim, West 
Table 1. Clinical characteristics at birth and at time of study (mean $\pm S D$ )

\begin{tabular}{lcc}
\hline & $\begin{array}{c}\text { HM group } \\
(n=8)\end{array}$ & $\begin{array}{c}\text { HM-Pr group } \\
(n=8)\end{array}$ \\
\hline Birth* & $30 \pm 1.4$ & $29.9 \pm 1.2$ \\
Gestational age (wk) & $1315 \pm 122$ & $1391 \pm 216$ \\
Birth wt (g) & $38.3 \pm 1.6$ & $39.4 \pm 1.1$ \\
Length (cm) & $27.6 \pm 0.9$ & $27.2 \pm 1.1$ \\
Head circumference (cm) & & \\
& & \\
Study* & $31 \pm 10$ & $33 \pm 11$ \\
Postnatal age (days) & $1653 \pm 267$ & $1799 \pm 109$ \\
Wt (g) & $42.1 \pm 2.1$ & $42.8 \pm 0.6$ \\
Length (cm) & $30.3 \pm 1.6$ & $30.5 \pm 1.0$ \\
Head circumference (cm) & $15.3 \pm 2.6$ & $17.1 \pm 2.2$ \\
Wt gain $\dagger(\mathrm{g} / \mathrm{kg} /$ day) & $1.1 \pm 0.3$ & $1.2 \pm 0.3$ \\
Length gain $\dagger(\mathrm{cm} /$ wk) & $1.0 \pm 0.1$ & $1.2 \pm 0.2$ \\
Head circumference gain $\dagger(\mathrm{cm} / \mathrm{wk})$ & \\
\hline
\end{tabular}

* No significant difference between the two groups at birth and at study.

† Calculated over the week overlapping the balance study.

Table 2. Macronutrient composition of cow's milk caseinhydrolysate (in $\mathrm{g} / 100 \mathrm{~g}$ of powder)

\begin{tabular}{lc} 
Total nitrogen & 13.2 \\
Free nitrogen & 0.2 \\
Lipids & 1.4 \\
Lactose & 0.2 \\
Sodium & 0.008 \\
Potassium & 0.010 \\
Magnesium & 0.037 \\
Calcium & 2.46 \\
Phosphorus & 1.08 \\
\hline
\end{tabular}

Germany). The caloric values representing the energy from combustion of nutrients $(9.3 \mathrm{kcal} / \mathrm{g}$ fat, $3.9 \mathrm{kcal} / \mathrm{g}$ carbohydrate, and $5.4 \mathrm{kcal} / \mathrm{g}$ protein) were used for calculations of the energy content of milks and losses. The amount of protein oxidized was calculated from urinary nitrogen output (the amount of nitrogen times 6.25) and a caloric value of $4.2 \mathrm{kcal} / \mathrm{g}$ was used for calculation of energy derived from protein oxidation because energy in urine derived from nitrogen metabolites (mainly urea) is equivalent to $1.2 \mathrm{kcal} / \mathrm{g}$ oxidized protein (10).

Indirect calorimetry measurements. During each balance study energy expenditure was measured using an open circuit system that allows continuous measurements of $\mathrm{VO}_{2}$ and $\mathrm{VCO}_{2}$. This technique uses a dual-channel paramagnetic $\mathrm{O}_{2}$ analyzer (Taylor Servomex OA 184) and an infrared $\mathrm{CO}_{2}$ analyzer (Beckman $\left.\mathrm{LB}_{2}\right)$ (11). $\mathrm{VO}_{2}, \mathrm{VCO}_{2}, \mathrm{RQ}$, and metabolic rate were calculated as described by Jequier (12). The accuracy of $\mathrm{VO}_{2}$ measurement was checked by a nitrogen dilution test (13) and that of the respiratory quotient by combustion of butane which yields a quotient of 0.61 . The infants were studied in their incubators within a thermoneutral environment (14). Periods of continuous measurements, usually performed during the 2 nd day of the balance study, varied from 6 to 15 hours (mean $\pm S D=8 \pm 2.5$ h).

Anthropometry. Weight and length gain and head circumference growth during each study were calculated from measurements taken 2 days before the beginning and 2 days after the end of the nutrient balance (i.e. over a 7-day period).

Laboratory data. At the beginning of the 3-day nutritional balance, a capillary blood sample was taken just before a feed in the two groups and $30 \mathrm{~min}$ after the same feed in the HM-Pr group. Total serum protein, blood urea nitrogen, and acid-base status were determined by standard methods (SMA II Technicon
Analyzer). Free amino acids were measured in a LKB 4150 amino acid analyzer with Norleucine as internal standard. Plasma was separated, deproteinized with $50 \%(\mathrm{w} / \mathrm{v})$ sulfosalicylic acid, and stored at $-20^{\circ} \mathrm{C}$ until analyzed.

Statistical analysis. The significance of differences between means was determined by the Student's $t$ test. All values are means $\pm \mathrm{SD}$.

\section{RESULTS}

During the study period there was no significant difference in weight, length, and head circumference gains between the two groups (Table 1).

As the volume of milk intake was slightly higher in the HM group, the total energy intake was similar in both groups (Table 3). The protein intake was significantly higher in infants fed HMPr. There was no significant difference in the digestibility of fat, nitrogen, and energy (Table 3 ). The amount of net protein (nitrogen $\times 6.25$ ) oxidized, calculated from nitrogen urinary output, was $1.0 \mathrm{~g} / \mathrm{kg} /$ day with HM-Pr as opposed to $0.49 \mathrm{~g} / \mathrm{kg} /$ day with HM. Nevertheless, nitrogen retention was $30 \%$ higher with HM-Pr than with HM. Casein hydrolysate supplementation resulted in significantly higher plasma concentration of essential and semiessential amino acids with the exception of cystine (Table 4). Blood urea nitrogen ( $2.8 \pm 0.9$ versus $1.5 \pm 0.3 \mathrm{mmol} /$ liter) and total serum protein $(49.9 \pm 2.1$ versus $44.1 \pm 4 \mathrm{~g} /$ liter $)$ levels were significantly higher in HM-Pr group than in HM group $(p<0.05)$, but there was no significant difference in bicarbonate level $(23.2 \pm 2.3$ versus $21.1 \pm 2.8 \mathrm{mmol} / \mathrm{liter}$, respectively).

Energy absorbed was identical in both groups (Table 3). Oxygen consumption was higher in the infants fed HM-Pr than in those fed HM $(8.32 \pm 0.57$ versus $6.92 \pm 0.80 \mathrm{ml} / \mathrm{kg} /$ day $p<$ $0.005)$ but the respiratory quotient was similar $(0.90 \pm 0.05$ and $0.88 \pm 0.03$, respectively). Energy expenditure was higher and energy storage lower in the group fed HM-Pr (Table 3).

\section{DISCUSSION}

The aim of this study was to evaluate the effects of supplementation of pooled HM with cow's milk casein hydrolysate on the growth rate, nitrogen and energy balances, and weight gain composition.

Table 3. Energy and macronutrients balances (mean $\pm S D$ )

\begin{tabular}{lrcc}
\hline & HM group & HM-Pr group & $p^{*}$ \\
\hline Volume intake (ml/kg/day) & $172 \pm 11.0$ & $164 \pm 7.0$ & NS \\
& & & \\
Nitrogen (mg/kg/day) & & & \\
$\quad$ Intake & $395 \pm 64$ & $602 \pm 80$ & $<0.001$ \\
$\quad$ Absorbed & $330 \pm 64$ & $486 \pm 64$ & $<0.005$ \\
$\quad$ Urine & $78 \pm 16$ & $160 \pm 64$ & $<0.005$ \\
$\quad$ Retained & $252 \pm 48$ & $326 \pm 32$ & $<0.01$ \\
& & & \\
Carbohydrate (g/kg/day) & & & \\
Intake & $10.7 \pm 0.9$ & $10.0 \pm 0.4$ & $\mathrm{NS}$ \\
& & & \\
Fat (g/kg/d) & & & \\
Intake & $5.6 \pm 0.5$ & $5.0 \pm 1.2$ & $\mathrm{NS}$ \\
$\quad$ Absorbed & $4.6 \pm 0.6$ & $3.8 \pm 1.6$ & $\mathrm{NS}$ \\
& & & \\
Energy (kcal/kg/day) & & & \\
$\quad$ Intake & $106.9 \pm 7.1$ & $105.6 \pm 14.2$ & $\mathrm{NS}$ \\
$\quad$ Absorbed & $95.4 \pm 8.4$ & $90.6 \pm 17.1$ & $\mathrm{NS}$ \\
$\quad$ Expended & $48.6 \pm 5.5$ & $57.9 \pm 3.6$ & $<0.005$ \\
$\quad$ Stored & $46.8 \pm 5.5$ & $32.7 \pm 13.8$ & $<0.05$ \\
$\quad$ Nonprotein energy stored & $38.3 \pm 7.7$ & $21.8 \pm 13.1$ & $<0.01$ \\
\hline
\end{tabular}

* Student's t test; NS: $\mathrm{p}>0.05$. 
Table 4. Concentration of plasma amino acids ( $\mu$ mol/dl) (mean $\pm S D)$

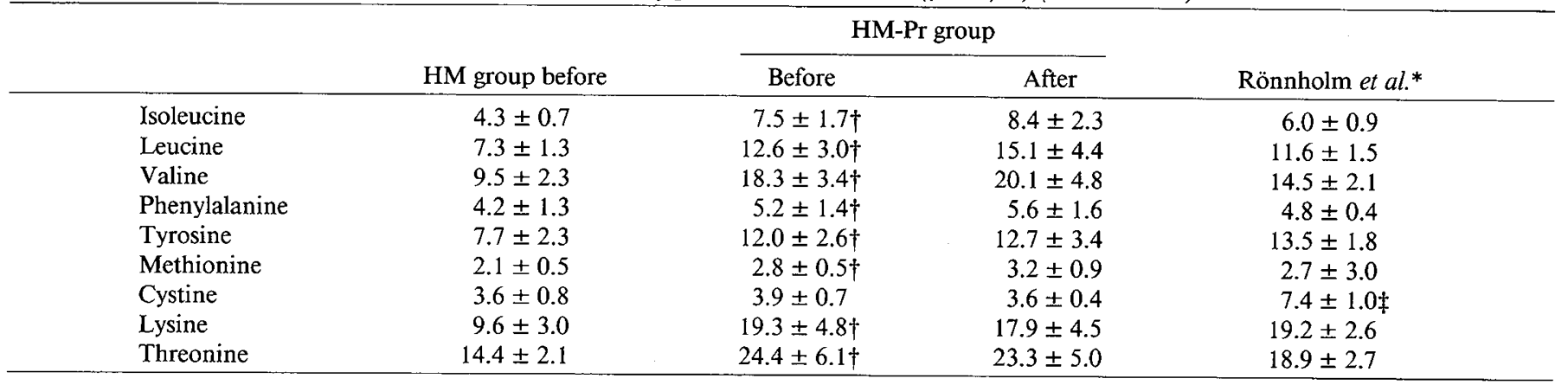

* VLBW infants fed human milk supplemented with human milk protein $(0.9 \mathrm{~g} / \mathrm{dl})(\mathrm{Ref} .26)$.

$\dagger$ Comparison between HM and HM-Pr group before the feed: $p<0.05$.

$\ddagger$ Cysteine value (and not cystine) is given by Rönnholm et al. (Ref. 26).

Growth rate. Weight, length, and head circumference gain was similar in both groups. However, the small number of infants and the short period of study do not allow us to draw definite conclusions. There are very few controlled studies $(6,7,15)$ on the effects of human milk supplementation with protein alone on the growth of VLBW infants and their results are controversial. In a first study Rönnholm et al. (6) demonstrated no difference in any of the measurements of growth between two groups of infants fed pooled banked human milk supplemented or unsupplemented with human milk protein. In contrast in two more recent studies $(7,15)$ the same authors concluded that human milk protein supplementation improves the growth of VLBW infants fed human milk.

Nitrogen balance. The low nitrogen retention seen in our HM group has already been reported in other balance studies using pooled or pasteurized HM given at around $180 \mathrm{ml} / \mathrm{kg} / \mathrm{day}(1$, 16). The higher nitrogen intake of the HM-Pr group resulted in a significantly higher urinary nitrogen excretion; this is in agreement with studies which show that urinary nitrogen excretion is well correlated with nitrogen intake $(8,17)$. Nevertheless, the nitrogen retention in the HM-Pr group was 30\% higher than in the HM group (326 versus $252 \mathrm{mg} / \mathrm{kg} /$ day) and achieved the nitrogen accretion rate of a fetus of the same gestational age (320 $\mathrm{mg} / \mathrm{kg} /$ day) $(18,19)$. Similar nitrogen retention has been found in infants fed their own mothers' milk $(20,21)$. The higher nitrogen intake in the HM-Pr group was associated with higher prefeeding plasma amino acid concentrations. This is not surprising, as there is a well-known correlation between plasma amino acid levels and protein intake $(22,23)$. Plasma amino acid levels taken immediately before a feed have been recommended for screening of any diet-induced, step-by-step accumulation of several amino acids, whereas postprandial amino acid measurements are a useful means of testing the infant's ability to handle amino acid loads in feeds (24). Collection of blood by heel puncture can increase plasma amino acids concentrations by contamination of the specimen with skin surface amino acids (25). This contamination is minimal in the premature infant and is reduced by washing and warming the skin (25). However, in our two groups sample collection was identical. In both groups plasma amino acid levels taken before a feed are within the range of those reported in preterm infants either fed human milk supplemented with human milk protein (26) (Table 4) or fed $200 \mathrm{ml} / \mathrm{kg} / \mathrm{day}$ of fresh human milk (4). In the HM-Pr group the postprandial increment of the plasma amino acid concentration is comparable to those reported in infants of similar gestational age fed either human milk or formula (24). The postprandial plasma amino acid levels are also below those reported in a fetus during the midtrimester of gestation $(27,28)$ and in the cord blood at birth $(8,29)$. We can thus assume that the nitrogen intake of the HM-Pr group did not result in excessive plasma amino acid levels.
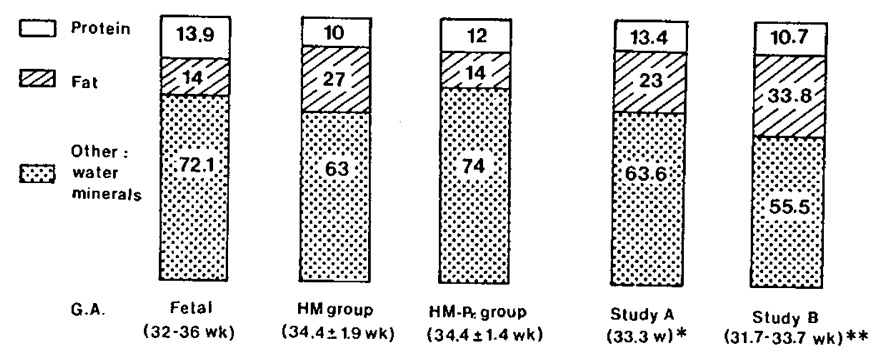

Fig. 1. Composition of weight gain (in percentage of total weight gain) in eight VLBW boys fed pooled HM (HM group) or casein hydrolysate supplemented HM (HM-Pr group). Caloric intakes were identical. For comparison values for 3rd trimester fetuses (Ref. 18) and for human milk fed VLBW infants from two other studies are presented ( $A$ and $B$, Refs. 21 and 30). Data from study $\mathrm{A}$ have been recalculated assuming that all nonprotein energy stored is fat. * Gestational age (mean) at study calculated from given data (Ref. 21 ). ${ }^{* *}$ Gestational age (range) at study calculated from given data (Ref. 30 ).

Energy balance. Energy intake and energy absorbed were similar in both groups. Energy expenditure was higher in the infants fed HM-Pr than in those fed HM (57.9 versus $48.6 \mathrm{kcal} /$ $\mathrm{kg} /$ day) but was well within reported values for growing low birth weight infants $((1,21,30)$. Energy expenditure is related to weight, postnatal age, activity, thermal environment, growth rate (31-33), and composition of feeds (34-36). In our study the only difference between the two groups was the higher nitrogen intake and retention. As protein synthesis is a main component of the metabolic rate, it is highly probable that the observed increase in energy expenditure was due to the higher nitrogen retention and possibly an increased protein turnover rate (35).

Weight gain composition. Weight gain was not significantly different between the two groups. Assuming that nonprotein energy is eventually stored as fat $(1,30,37)$, one can calculate that $2.4 \mathrm{~g} / \mathrm{kg} /$ day (i.e. $4.3 \mathrm{~g} /$ day) is deposited in the HM-Pr group versus $4.1 \pm 0.8 \mathrm{~g} / \mathrm{kg} /$ day (i.e. $6.9 \mathrm{~g} /$ day) in the HM group. This represents 14 and $27 \%$ of the weight gain, respectively (Fig. 1). By comparison $14 \%$ of the weight gain (i.e. $4.3 \mathrm{~g} /$ day) is deposited as fat by the fetus of the same gestational age. Much higher fat storage than in utero has been reported in VLBW infants fed either formula $(1,30,38)$ or human milk $(1,30)$. In infants fed their own mothers' milk (21) fat storage has been said to be $16 \%$ of the weight gain. However, in that study (21) a daily carbohydrate storage of $3 \mathrm{~g} / \mathrm{kg}$ was not taken into account; if one assumes that all nonprotein energy is eventually deposited as fat (37), fat storage would represent $23 \%$ of the weight gain (Fig. 1), which is similar to the results published by Whyte et al. (30) (Fig. 1). Protein accretion was $2.02 \mathrm{~g} / \mathrm{kg} /$ day or $12 \%$ of the weight gain in the HM-Pr group (Fig. 1) and $1.58 \mathrm{~g} / \mathrm{kg} /$ day or $10 \%$ in the HM group. In utero the protein gain is around $2 \mathrm{~g} /$ 
$\mathrm{kg} /$ day or $14 \%$ of the weight gain $(18,19)$. When protein retention is related to fat-free weight gain, the ratio is $14 \%$ in the HMPr group and $13.5 \%$ in the HM group, which is similar to that in utero (15\%).

In conclusion, our data confirm that VLBW infants fed pooled HM have low nitrogen retention and high fat deposition compared to the fetus. Supplementation of pooled HM with cow's milk casein hydrolysate, without increasing energy intake, resulted in a better nitrogen retention, a higher energy expenditure, a lower fat deposition, and a weight gain composition similar to that in utero. This was achieved without metabolic imbalance.

\section{REFERENCES}

1. Putet G, Senterre J, Rigo J, Salle B 1985 Nutrient balance, energy utilization and composition of weight gain in very-low-birth weight infants feed pooled human milk or a preterm formula. J Pediatr 105:79-85

2. Brooke OG, Wood C, Barley J 1982 Energy balance, nitrogen balance and growth in preterm infants fed expressed breast milk, a premature infant formula and two low-solute adapted formulas. Arch Dis Child 57:898-904

3. Lucas A, Core SM, Cole TJ, Bamford MF, Dossetor JBF, Barr I, Dicarlo L, Cork S, Lucas PJ 1984 Multicentre trial on feeding low birth weight infants: effects of diet on early growth. Arch Dis Child 59:722-730

4. Tyson JE, Lasky RE, Mize CE, Richards CJ, Blair-Smith N, Whyte R, Beer AE 1983 Growth, metabolic response, and development in very-low birth weight infants fed banked human milk or enriched formula. I. Neonatal findings. J Pediatr 103:95-104

5. Gross SJ 1983 Growth and biochemical response of preterm infants fed human milk or modified infant formula. N Engl J Med 308:237-241

6. Rönnholm KAR, Sipiläi, Siimes MA 1982 Human milk protein supplementation for the prevention of hypoproteinemia without metabolic imbalance in breast milk-fed very low-birth weight infants. J Pediatr 101:243-247

7. Rönnholm KAR, Siimes MA 1985 Haemoglobin concentration depends on protein intake in small preterm infants fed human milk. Arch Dis Child 60:99-104

8. Senterre J 1979 Nitrogen balances and protein requirement of preterm infants. In: Visser HKA (ed) Nutrition and Metabolism of the Fetus and Infant. Martinus Nijhoff, The Hague, pp 195-212

9. Codex Alimentarius Commission 1982 Methods of analysis for food for infants and children. In: Codex Alimentarius, Vol 9, Ed 1. Joint FAO/WHO Food Standards Programme. Rome, Food and Agriculture Organization of the United Nations, p 36

10. Best CH, Taylor NB 1950 The physiological basis of medical practice, Ed 8 . 1968 Williams \& Wilkins Co, Baltimore, pp 741-763

11. Swyer PR, Putet G, Smith JM, Heim T 1978 Energy metabolism and substrate utilisation during total parenteral nutrition in the newborn. In: Stern $\mathcal{L}$, Oh W, Friis-Hansen B (eds) Intensive Care in the Newborn. II. Masson, New York, pp 307-316

12. Jequier E 1980 Métabolisme énergétique. Encycl Med Chir Paris Nutr 10371(A10): 11

13. Kappagoda CR, Linden RJ 1972 A critical assessment of an open circuit technique for measuring oxygen consumption. Cardiovasc Res 6:589-598

14. Hey EN, Katz G 1970 The optimum thermal environment for naked babies. Arch Dis Child 45:328-334

15. Rönnholm KAR, Perheentupa J, Siimes MA 1986 Supplementation with human milk protein improves growth of small premature infants fed human milk. Pediatrics 77:649-653

16. Schanler RJ, Oh W 1985 Nitrogen and mineral balance in preterm infants fed human milks or formula. J Pediatr Gastroenterol Nutr 4:214-219

17. Snyderman SE, Boyer A, Kogut MD, Holt LE 1969 The protein requirement of the premature infants. I. The effect of protein intake of the retention of nitrogen. J Pediatr 74:872-880

18. Ziegler EE, O'Donnell A, Nelson SE, Fomon SJ 1976 Body composition of the reference fetus. Growth 40:329-341

19. Widdowson EM 1980 Importance of nutrient in development with special reference to feeding the low birthweight infant. Proceedings of the Ross Clinical Research Conference, Meeting Nutritional Goals for Low-BirthWeight Infants. Tarpon Springs, FL, pp 4-11

20. Atkinson SA, Bryan H, Anderson GH 1981 Human milk feeding in premature infants: protein, fat, and carbohydrate balances in the first two weeks of life. J Pediatr 99:617-624

21. Chessex P, Reichman B, Verellen G, Putet G, Smith JM, Heim T, Swyer PR 1983 Quality of growth in premature infants fed their own mother's milk. J Pediatr 102:107-112

22. Snyderman SE, Holt LE, Norton PM, Roitman E, Phansalkar SV 1968 The plasma aminogram. I. Influence of the level of protein intake and comparison of whole protein and amino acid diets. Pediatr Res 2:131-144

23. Raïha NCR, Heinonen K, Rassin DK, Gaull GE 1976 Milk protein quality and quantity in low birth weight infants. I. Metabolic responses and effects on growth. Pediatrics 57:659-674

24. Tikanoja T, Simell O, Järvenpää AL, Räihä NC 1982 Plasma amino-acids in preterm infants after a feed of human milk or formula. J Pediatr 101:248252

25. Stegink LD, Filer LJ, Baker GL 1982 Effect of sampling site on plasma aminoacid concentrations of infants: effect of skin amino-acids. Am $\mathbf{J}$ Clin Nutr 36:917-925

26. Rönnholm KAR, Simell O, Siimes MA 1984 Human milk protein and medium-chain triglyceride oil supplementation of human milk: Plasma amino-acids in very low-birth weight infants. Pediatrics 74:792-799

27. McIntosh N, Rodeck CH, Heath R 1984 Plasma aminoacids of the mid trimester human fetus. Biol Neonate 45:218-224

28. Soltesz G, Harris D, Mackenzie IZ, Aynsley-Green A 1985 The metabolic and endocrine milieu of the human fetus and mother at 18-21 weeks of gestation. I. Plasma amino acid concentrations. Pediatr Res 19:91-93

29. Rigo J 1980 Contribution à l'étude de l'apport optimal en acides aminés chez le prématuré alimenté par voie orale ou parentérale. Thesis, University of Liege, pp 1-124

30. Whyte RK, Haslam R, Vlainic C, Shannons, Samulski K, Campbell D, Bayley HS, Sinclair JC 1983 Energy balance and nitrogen balance in growing lowbirth-weight infants fed human milk or formula. Pediatr Res 17:891-898

31. Hill JR, Rahimtulla KA 1965 Heat balance and the metabolic rate of newborn babies in relation to environmental temperature and the effect of age and weight on basal metabolic rate. J Physiol 180:239-265

32. Chessex P, Reichman BL, Verellen G, Putet G, Smith J, Heim T, Swyer PR 1981 Influence of postnatal age, energy intake and weight gain on energy metabolism in the very-low-birth weight infant. J Pediatr 98:761-766

33. Reichman BL, Chessex P, Putet G, Verellen G, Smith JM, Heim T, Swyer PR 1982 Partition of energy metabolism and energy cost of growth in the very low birth weight infant. Pediatrics 69:446-451

34. Baba N, Bracco EF, Hashim SA 1982 Enhanced thermogenesis and diminished deposition of fat in response to overfeeding with diet containing mediumchain triglyceride. Am J Clin Nutr 35:678-682

35. Catzeflis C, Schutz Y, Micheli JL, Welsch C, Arnaud MJ, Jequier E 1985 Whole body protein synthesis and energy expenditure in very low birth weight infants. Pediatr Res 19:679-687

36. Brooke OG 1980 Energy balance and metabolic rate in preterm infants fed with standard and high-energy formulas. $\mathrm{Br} \mathrm{J}$ Nutr 44:13-23

37. Widdowson EM 1981 Changes in body composition during growth. In: Davis JA Dobbing J (eds) Scientific Foundation of Pediatrics. Heinemann, London, pp 330-342

38. Reichman B, Chessex P, Putet G, Verellen G, Smith J, Heim T, Swyer PR 1981 Diet, fat accretion and growth in premature infants. N Engl J Med 305:1495-1500 